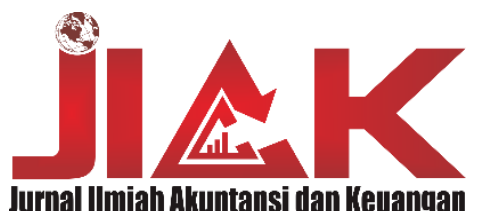

http://journal.stieputrabangsa.ac.id/index.php/jiak

ISSN: 2580-510X/ P-ISSN: 2548-9453

ARTICLE INFORMATION

Received June $6^{\text {th }} 2020$

Accepted January $28^{\text {th }} 2021$

Published January $31^{\text {st }} 2021$

DOI:

https://doi.org/10.32639/jiak. v9i2.595

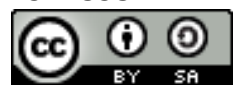

\section{Analisis Karakteristik Perusahaan Terhadap Kebijakan Dividen pada Perusahaan Manufaktur Sektor Industri Dasar dan Kimia yang Terdaftar Di BEI}

\author{
Isnaeni Rokhayati ${ }^{1}$, Harsuti ${ }^{2}$, Devi Puji Lestari ${ }^{3}$ \\ 1,2,3) Universitas Wijayakusuma Purwokerto \\ email: isnaeni_akbar@yahoo.co.id ${ }^{1}$
}

\begin{abstract}
ABSTRAK
Tujuan penelitian ini adalah untuk mengetahui bagaimana pengaruh karaktersitik perusahaan berupa variabel likuiditas, profitabilitas, dan ukuran perusahaan terhadap kebijakan dividen pada perusahaan manufaktur di industri dasar dan sektor kimia yang terdaftar di Bursa Efek Indonesia. Penelitian merupakan penelitian kuantitatif yang menggunakan data sekunder. Sampel dalam penelitian sebanyak 15 perusahaan yang dipilih dengan metode purposive sampling. Metode analisis data menggunakan analisis regresi linier berganda. Hasil analisis menunjukan bahwa karakteristik perusahaan dapat mempengaruhi kebijakan deviden perusahaan. Variabel profitabilitas dan ukuran perusahaan dapat memengaruhi kebijakan deviden, sedangkan variabel likuiditas tidak memliki pengaruh. Diharapkan dengan mengetahi faktor apa saja yang mempengaruhi kebijkan dividen, perusahaan akan lebih mengutamakan kinerja perusahaan terkait dengan peningkatan keuntungan perusahaan dan ukuran perusahaan.
\end{abstract}

Kata kunci: Likuiditas; Profitabilitas; Ukuran Perusahaan; Kebijakan Dividen; Karakteristik Perusahaan

\begin{abstract}
The purpose of this study was to determine how the influence of company characteristics in the form of liquidity, profitability, and company size variables on dividend policy in manufacturing companies in the basic industries and chemical sectors listed on the Indonesia Stock Exchange. The research is a quantitative study that uses secondary data. Samples in the study were 15 companies selected by purposive sampling method. The method of data analysis uses multiple linear regression analysis. The analysis shows that the characteristics of the company can influence the company's dividend policy. The variable profitability and company size can influence dividend policy, while the liquidity variable has no effect. It is expected that by knowing what factors influence the dividend policy, the company will prioritize the company's performance related to increasing company profits and company size.
\end{abstract}

Keywords: Liquidity; Profitability; Company Size; Dividend Policy; Company Characteristics 


\section{PENDAHULUAN}

Perekonomian di era globalisasi yang semakin ketat menuntut persaingan usaha bagi perusahaan go public, tidak hanya dalam satu sektor industri melainkan antar sektor industri. Pasar modal dipandang mampu membantu keuangan perusahaan dengan menjual atau membeli saham kepada investor. Pasar modal adalah pertemuan antara pihak yang memiliki kelebihan dana dengan pihak yang membutuhkan dana dengan cara menjual dan membeli sekuritas. Investor merupakan pihak-pihak yang melakukan kegiatan investasi (Tandelilin, 2001)

Saham menjadi salah satu pilihan dari berbagai alternatif investasi yang terdapat dipasar modal. Tujuan perusahaan melakukan investasi saham adalah selain untuk mendapatkan tambahan modal, untuk memperluas operasional perusahaan sehingga memperbesar laba, serta untuk memakmurkan para pemegang sahamnya. Perusahaan merupakan salah satu penggerak perekonomian utama pada suatu negara. Suatu perusahaan harus menjaga nilai perusahaannya guna menjaga keberlangsungan hidup perusahaan dimasa yang akan datang. Tidak hanya perusahaan-perusahaan biasa saja yang melaksanakan proses aktivitas keuangan dalam mencapai tujuanya, sama halnya dengan perusahaan yang berada di Bursa Efek Indonesia (Wijayanto dan Anggi, 2018).

\section{KAJIAN LITERATUR DAN PENGEMBANGAN HIPOTESIS}

Dividen adalah bagian laba perusahaan yang diterima oleh pemegang saham berdasarkan banyaknya saham yang dimiliki. Dividen bisa berbentuk kas, aktiva lain, surat atau bukti lain yang menyatakan hutang perusahaan kepada pemegang saham sebagai proporsi dari sejumlah saham yang dimiliki oleh pemilik. Kebijakan dividen (dividend policy) adalah keputusan apakah laba yang diperoleh perusahaan akan dibagikan kepada pemegang saham sebagai dividen, atau akan ditahan dalam bentuk laba ditahan guna pembiayaan investasi dimasa mendatang (Sartono, 2001).

Likuiditas adalah kemampuan perusahaan dalam memenuhi kewajiban jangka pendek tepat pada waktunya. Likuiditas perusahaan di tunjukkan oleh besar kecilnya aktiva lancar yaitu kas, surat berharga, piutang, dan persediaan (Sartono, 2001). Penelitian sebelumnya tentang likuiditas berpengaruh negatif terhadap kebijakan dividen pernah dilakukan oleh Hudiwijono et al (2018), Wijayanto dan Anggi (2018). Sedangkan penelitian tentang likuiditas berpengaruh positif terhadap kebijakan dividen pernah dilakukan oleh Apriliani dan Kartina (2017), Mustawa (2017), Ginting S. (2018), Finingsih, Siti dan Kartika (2018).

Profitabilitas adalah kemampuan perusahaan dalam mendapatkan laba yang hubungannya dengan penjualan, total aktiva, maupun modal sendiri (Sartono, 2001). Penelitian terdahulu tentang profitabilitas berpengaruh positif terhadap kebijakan dividen pernah dilakukan oleh Manneh dan Kamal (2015), Ma'rufiatin dan Purwohandoko (2018), Rifqi dan Erman (2018). Sedangkan penelitian tentang profitabilitas berpengaruh negatif terhadap kebijakan dividen pernah di lakukan oleh Lopulosi (2013), Ginting dan Munawarah (2018), Morakinyo et al (2018), dan Suroto (2015).

Ukuran perusahaan merupakan ukuran besar kecilnya sebuah perusahaan yang di tunjukkan atau dinilai oleh total asset, total penjualan, jumlah laba, beban pajak, dan lain-lain (Brigham dan Joel, 2010). Penelitian terdahulu yang dilakukan oleh Simanjutak (2016), Apriliani dan Kartina (2017), Manneh dan Kamal (2015), Morakinyo et al (2018), dan Rifqi dan Erman (2018) menunjukkan bahwa ukuran perusahaan berpengaruh positif terhadap kebijakan dividen. Sedangkan penelitian yang dilakukan oleh Hudiwijono et al (2018), Oktaviani dan Sautma (2015), menunjukkan bahwa ukuran perusahaan berpengaruh negatif terhadap kebijakan dividen.

Manajer sebagai agen pengelola harus mampu menghasilkan keuntungan yang akhirnya dapat memenuhi kebutuhan dana perusahaan dan investornya dengan mempertimbangkan kondisi perusahaan saat ini, 
keinginan perusahaan di masa mendatang dan faktor-faktor yang mempengaruhi kebijakan dividen. Ada beberapa faktor yang dapat mempengaruhi kebijakan dividen pada penelitian ini adalah likuiditas, profitabilitas dan ukuran perusahaan. Berdasarkan pada uraian diatas, maka hipotesis penelitian adalah:

H1: likuiditas berpengaruh terhadap kebijakan dividen

$\mathbf{H}_{2}$ : profitabilitas berpengaruh terhadap kebijakan dividen

H3: ukuran perusahaan berpengaruh terhadap kebijakan dividen

\section{METODE PENELITIAN}

Penelitian ini merupakan penelitian kuantitatif karena didalamnya mengacu pada perhitungan data berupa angka (Sugiyono, 2017). Objek penelitian ini adalah likuiditas, profitabilitas, ukuran perusahaan dan kebijakan dividen pada perusahaan manufaktur sektor industri dasar dan kimia yang terdaftar di Bursa Efek Indonesia (BEI) periode 2016-2018.

Populasi dalam penelitian ini sebanyak 70 perusahaan manufaktur sektor industri dasar dan kimia (basic industry and chemicals) yang terdaftar di Bursa Efek Indonesia (BEI) periode 2016 - 2018. Sampel merupakan bagian dari jumlah dan karakteristik yang dimiliki oleh populasi tersebut (Sugiyono, 2017). Teknik pengambilan sampel yang digunakan dalam penelitian ini adalah dengan teknik purposive sampling, diperoleh sampel sebanyak 15 perusahaan manufaktur sektor industri dasar dan kimia yang terdaftar di BEI periode 2016-2018.

Kebijakan dividendal merupakan keputusan yang diambil perusahaan terhadap laba yang diperoleh perusahaan pada perusahaan manufaktur sektor industri dasar dan kimia yang terdaftar di BEI periode 2016 - 2018. Kebijakan dividen dapat diukur dengan skala rasio dan dapat dihitung dengan menggunakan dividend payout ratio sebagai berikut (Gumanti, 2013):

$$
\text { DPR }=\frac{\text { Dividen Per Lembar Saham }}{\text { Laba Bersih Per Lembar Saham }} \times 100 \%
$$

Likuiditas merupakan kemampuan membayar kewajiban jangka pendek tepat waktu pada perusahaan manufaktur sektor industri dasar dan kima yang terdaftar di BEI Periode 2016 - 2018. Likuiditas dalam penelitian ini dapat diukur dengan current ratio. Current ratio merupakan perbandingan antara aktiva lancar dengan utang lancar (Sartono, 2001):

$$
\mathrm{CR}=\frac{\text { Aktiva Lancar }}{\text { Utang Lancar }} \times 100 \%
$$

Profitabilitas merupakan kemampuan perusahaan memperoleh laba pada perusahaan manufaktur sektor industri dasar dan kimia yang terdaftar di BEI periode 2016-2018. Profitabilitas diukur dengan menggunakan Return on Equity (ROE) dengan rumus sebagai berikut (Sartono, 2001):

$$
\mathrm{ROE}=\frac{\text { Laba Bersih Setelah Pajak (EAT) }}{\text { Ekuitas Pemegang Saham }} \times 100 \%
$$

Ukuran perusahaan merupakan ukuran atau bsarnya asset yang dimiliki perusahaan manufaktur sektor industri dasar dan kimia yang terdaftar di BEI periode 2016 - 2018. Ukuran perusahaan pada penelitian ini diukur dengan logaritma natural dari total asset (LnTA) tiap tahun dengan rumus sebagai berikut (Samrotun, 2015 dalam Apriliani dan Kartina, 2017): 


$$
\text { Size }=\text { Log Natural Total Asset (LnTA) }
$$

Metode analisis yang digunakan regresi linear berganda. Asumsi klasik merupakan pengujian untuk mengetahui apakah hasil estimasi regresi yang dilakukan menunjukan hubungan yang valid atau BLUE (Best Liner Unbiased Estimator) yaitu terbebas dari adanya gejala normalitas, multikolinieritas, heteroskedastisitas dan autokorelasi.

\section{HASIL PENELITIAN DAN PEMBAHASAN}

\section{Uji Hipotesis}

Hasil uji t menunjukkan bahwa signifikansi variabel likuiditas yaitu Current Ratio (CR) yaitu 0,752 lebih besar dari 0,05 dengan nilai t hitung -0,319 lebih besar dari t tabel -2,019. Hal ini menunjukkan bahwa CR mempunyai pegaruh yang tidak signifikan terhadap kebijakan dividen. Dengan demikan maka hipotesis pertama yang menyatakan bahwa likuiditas berpengaruh signifikan terhadap kebijakan dividen perusahaan manufaktur sektor industri dasar dan kimia yang terdaftar di BEI ditolak.

Hasil penelitian ini konsisten dengan temuan Oktaviani dan Sautma (2015), Ong Chun Lin et al (2018), dan Wijayanto dan Anggi (2018) yang menunjukkan bahwa likuiditas berpengaruh negatif dan tidak signifikan terhadap kebijakan dividen. Hasil penelitian menunjukkan likuiditas memiliki pengaruh yang tidak signifikan terhadap kebijakan dividen bisa disebabkan karena perusahaan yang memiliki likuiditas yang tinggi tidak bisa menjamin tingkat pembayaran dividen perusahaan tersebut tetapi hanya menandakan bahwa kas yang dimiliki perusahaan cukup banyak (Munawir, 2012 dalam Wijayanto dan Anggi, 2018).

Hasil penelitian ini tidak sesuai dengan teori sinyal yang menyatakan bahwa tingginya tingkat likuiditas perusahaan memberikan sinyal bahwa kas yang dimiliki perusahaan cukup banyak, sehingga kemungkinan dividen dibagikan cukup tinggi. Likuiditas memang menjadi alat untuk menunjukkan kemampuan perusahaan dalam memenuhi kewajiban finansial jangka pendeknya. Namun, bukan berarti kelancaran pembayaran hutang jangka pendek bisa memberikan kesimpulan bahwa perusahaan pasti akan membayarkan dividen kepada para pemegang sahamnya.

Hal tersebut bisa disebabkan karena adanya pertimbangan lain seperti keputusan pendanaan, adanya peluang investasi, peraturan perundang-undangan, atau dampak yang akan terjadi pada kinerja perusahaan selanjutnya jika melakukan pembayaran dividen (Hardiatmo dan Daljono, 2013 dalam Wijayanto dan Anggi, 2018). Pertimbangan dalam pembagian dividen kepada pemegang saham menjadikan pengaruh Current Ratio (CR) terhadap Dividend Payout Ratio (DPR) tidak signifikan, artinya pembagian dividen perusahaan kepada pemegang saham tidak bergantung pada tingkat likuiditas perusahaan yang bersangkutan.

Hasil analisis menunjukkan bahwa signifikansi variabel profitabilitas yaitu Return On Equity (ROE) yaitu 0,000 lebih kecil dari 0,05 dengan nilai t hitung -4,167 lebih kecil dari t tabel -2,019. Hal ini menunjukan bahwa ROE mempunyai pengaruh yang signifikan terhadap kebijakan dividen. Dengan demikian maka hipotesis kedua yang menyatakan bahwa profitabilitas berpengaruh signifikan terhadap kebijakan dividen pada perusahaan manufaktur sektor industri dasar dan kimia yang terdaftar di BEI diterima.

\section{Pembahasan}

Hasil penelitian ini konsisten dengan studi yang dilakukan oleh Suroto (2015) yang menunjukkan bahwa semakin tinggi ROE maka akan semakin rendah kebijakan dividennya. Nilai ROE yang tinggi dapat mencerminkan kemampuan perusahaan dalam mengelola modal sendiri secara efektif untuk menghasilkan laba. Namun, besarnya laba yang dihasilkan perusahaan dari pengelolaan modal sendiri 
tidak bisa memberikan jaminan atas kesimpulan bahwa Dividend Payout Ratio yang dibagikan akan ikut meningkat. Hal ini dikarenakan keuntungan setelah pajak yang diperoleh perusahaan tidak sepenuhnya digunakan untuk membayar dividen kepada pemegang saham, tetapi keuntungan setelah pajak yang diperoleh perusahaan sebagian dijadikan sebagai laba ditahan yang dimaksudkan untuk ekspansi dimasa mendatang.

Hasil penelitian ini sesuai dengan teori preferensi pajak, dimana teori ini menjelaskan bahwa semakin tinggi profitabilitas perusahaan perusahaan akan menurunkan pembayaran dividen kepada para pemegang sahamnya. Hal ini dikarenakan ROE merupakan laba yang dihasilkan dari modal sendiri sehingga kemungkinan terkena pajak penghasilan atas dividen juga tinggi. Bagi investor yang tidak menyukai pajak, akan memutuskan untuk tidak menerima dividen karena pengenaan pajak yang tinggi. Selain itu, tingginya ROE disebabkan karena profit yang inkonsisten, utang yang berlebihan, adanya kerugian, dan lain-lain.

Penelitian ini menunjukkan bahwa kenaikan ROE menurunkan Dividen Payot Ratio, tetapi ROE memiliki pengaruh yang signifikan terhadap kebijakan dividen perusahaan. Dengan tingkat ROE yang tinggi berarti kinerja manajemen dalam mengelola modal sendiri dinilai cukup baik, sehingga kenaikan pendapatan atas modal sendiri mampu meningkatkan kemampuan pendanaan internal perusahaan yang berakibat meningkatkan laba dimasa mendatang. Dengan demikian, dalam membuat keputusan mengenai kebijakan dividen, harus mempertimbangkan ROE perusahaan yang bersangkutan.

Analisis uji t menunjukkan bahwa signifikansi variabel ukuran perusahaan sebesar 0,015 lebih kecil dari 0,05 dengan nilai t hitung 2,542 lebih besar dari t tabel yaitu 2,019. Hal ini menunjukkan bahwa Size mempunyai pengaruh yang signifikan terhadap kebijakan dividen. Dengan demikian maka hipotesis ketiga yang menyatakan bahwa ukuran perusahaan berpengaruh signifikan terhadap kebijakan dividen pada perusahaan manufaktur sektor industri dasar dan kimia yang terdaftar di BEI diterima.

Hasil penelitian ini konsisten dengan temuan Ma'rufiatin dan Purwohandoko (2018), Morakinyo et al (2018), dan Apriliani dan Kartina (2017) yang menunjukkan bahwa ukuran perusahaan mempunyai pengaruh yang positif dan signifikan terhadap kebijakan dividen perusahaan manufaktur sektor industri dasar dan kimia yang terdaftar di Bursa Efek Indonesia tahun 2016-2018. Hubungan ini mengindikasikan bahwa semakin besar ukuran perusahaan akan diikuti oleh tingginya tingkat dividend payout ratio perusahaan yang bersangkutan dan memiliki pengaruh yang signifikan terhadap kebijakan dividen perusahaan manufaktur sektor industri dasar dan kimia yang terdaftar di Bursa Efek Indonesia tahun 2016-2018.

Pengaruh yang positif mengindikasikan bahwa ukuran perusahaan yang semakin besar dan mapan memiliki kemudahan akses perusahaan kepasar modal. Artinya, semakin besar perusahaan maka fleksibilitas dan kemudahan perusahaan dalam mencari dana akan semakin besar sehingga mengakibatkan dividen yang dibagikan juga semakin tinggi. Hasil penelitian ini sesuai dengan teori sinyal (signalling theory) yang menyatakan bahwa semakin tinggi pembayaran dividen maka semakin baik prospek perushaan dimasa mendatang. Hal ini menunjukkan bahwa ukuran perusahaan memiliki pengaruh dalam kebijakan dividen.

Pengaruh ukuran perusahaan terhadap kebijakan dividen perusahaan tidak bisa diabaikan. Hal ini dikarenakan kemudahan akses ke pasar modal memudahkan perusahaan memperoleh dana sehingga dapat membantu perusahaan dalam memperluas operasional usahanya. Dengan semakin besar ukuran perusahaan, diharapkan laba yang dihasilkan juga semakin tinggi. Tingginya laba perusahaan menyebabkan kemampuan perusahaan dalam membayarkan dividen semakin meningkat, citra perusahaan dimata publik semakin baik, dan kepercayaan dari para partner bisnis semakin kuat. Dengan demikian, dalam membuat keputusan mengenai kebijakan dividen sebaiknya mempertimbangkan ukuran perusahaan yang bersangkutan karena ukuran perusahaan memiliki pengaruh yang signifikan terhadap kebijakan dividen. 


\section{SIMPULAN}

Variabel likuiditas tidak berpengaruh signifikan terhadap kebijakan dividen perusahaan manufaktur sektor industri dasar dan kimia yang terdaftar di Bursa Efek Indonesia tahun 2016-2018. Tingkat signifikansi variabel likuiditas sebesar 0,752 dengan nilai t hitung sebesar -0,319. Variabel profitabilitas berpengaruh signifikan terhadap kebijakan dividen perusahaan manufaktur sektor industri dasar dan kimia yang terdaftar di Bursa Efek Indonesia tahun 2016-2018. Tingkat signifikansi variabel profitabilitas sebesar 0,000 dengan nilai t hitung sebesar -4,167. Dan variabel ukuran perusahaan berpengaruh signifikan terhadap kebijakan dividen perusahaan manufaktur sektor industri dasar dan kimia yang terdaftar di Bursa Efek Indonesia tahun 2016-2018. Tingkat signifikansi variabel size sebesar 0,015 dengan nilai t hitung sebesar 2,542.

Kebijakan dividen mengindikasikan bahwa untuk membuat keputusan kebijakan dividen yang tepat sebaiknya memperhatikan kinerja perusahaan terkait dengan rasio profitabilitas dan ukuran perusahaan. Upaya yang dapat dilakukan yaitu dengan melakukan evaluasi secara periodik baik triwulanan, semesteran, maupun tahunan berkaitan dengan laba, ekuitas dan total aset, melakukan pengendalian biaya secara efisien guna meningkatkan pendapatan dan laba bersih perusahaan.

Keterbatasan penelitian ini antara lain hanya melakukan penhamatan dalam tiga tahun saja, sehingga untuk penelitian yang akan datang bisa melakukan tahun pengamatan yang lebih lama. Variabel yang diamati hanya likuiditas, profitabilitas, dan ukuran perusahaan. Untuk penelitian yang akan datang bita ditambahkan variabel pengamatan yang lain seperti tingkat suku bunga, inflasi, kebijakan ekonomi, dan solvabilitas.

\section{REFERENSI}

Apriliani, A., \& Natalylova, K. (2017). Faktor-faktor yang mempengaruhi kebijakan dividen pada perusahaan manufaktur di Bursa Efek Indonesia. Jurnal Bisnis dan Akuntansi, 19(1a-1), 49-57.

Brigham, E. F., \& Houston, J. F. (2010). Dasar - Dasar Manajemen Keuangan Buku I Edisi 11. Salemba Empat. Jakarta.

Finingsih, O., Nurlaela, S., \& Titisari, K. H. (2018, August). The Influence of Profitability, Liquidity, Leverage, and Company Growth to Dividend Policy on Agricultural Companies In Indonesia Stock Exchange. In PROCEEDING ICTESS (Internasional Conference on Technology, Education and Social Sciences), 427-437.

Ginting, S. (2018). Pengaruh Likuiditas, Profitabilitas. Dan Leverage Terhadap Kebijakan Deviden Pada Perusahaan Lq45 Yang Terdaftar Di Bursa Efek Indonesia Periode 2012-2016. Jurnal Wira Ekonomi Mikroskil: JWEM, 8(2), 195-204.

Ginting, W. A., \& Munawarah, M. 2018. Analisis Faktor-Faktor Yang Mempengaruhi Kebijakan Dividen. Jurnal Akuntansi dan Bisnis, 4(1), 21-37.

Gumanti, T. A. (2013). Kebijakan Dividen Teori, Empiris, dan Implikasi. UPP STIM YKPN. Yogyakarta.

Hery. (2016). Analisis Laporan Keuangan Integrated and Comprehensive Edition. PT Grasindo. Jakarta.

Ma'Rufatin, R., \& Purwohandoko, M. M. (2018). The Influence Of Profitability, Sales Growth, Leverage, Company's Size, And Free Cash Flow Toward Dividend Policy: A Study On Infrastructure Sector Companies, Utility, And Transportation Listings IDX 2010-2014 Period. Journal of Research and Opinion, 5(11). 
Manneh, M., Marwah A., \& Kamal N. (2015). Determinants of Corporate Dividend Policy: Evidence of a Emerging Economy. International Journal of Economic and Finance, 7(7).

Margaretha, F. (2014). Dasar-dasar Manajemen Keuangan. Jakarta: Dian Rakyat.

Morakinyo, F. O., David, J. O., Adeleke, E. O., \& Omojola, S. O. (2018). Determinants of dividend policy of listed deposit money banks in Nigeria. World Journal of Finance and Investment Research (International Institute of Academic Research and Development), 3(1), 25-40.

Rifqi, A., \& Arfianto, E. D. (2018). The Influence of Profitability, Debt To Equity Ratio, Firm Size, Innovation, And Time Discounting To Dividend Payout Ratio (Case Study on Manufacturing Companies Listed on Indonesia Stock Exchange 2012-2017). Diponegoro Journal of Management, 7(4), 44-54.

Sartono, A. (2001). Manajemen Keuangan Teori dan Aplikasi. edisi 4. BPFE. Yogyakarta.

Simanjuntak, S. M. (2018). Pengaruh return on asset, growth, total Asset turnover, ownership, firm size dan debt to total asset terhadap dividend payout ratio pada perusahaan yang terdaftar di bursa efek indonesia periode 2010-2012. Jurnal Lentera Akuntansi, 2(2), 101-116.

Sugiyono. (2017). Statistika Untuk Penelitian. CV. Alfabeta. Bandung.

Suliyanto. (2011). Ekonometrika Terapan: Teori \& Aplikasi dengan SPSS. Andi. Yogyakarta.

Suroto, S. (2015). Faktor-Faktor Yang Mempengaruhi Dividend Payout Ratio Pada Perusahaan Yang Terdaftar Di Bursa Efek Indonesia Periode 2010-2012. Serat Acitya, 4(1), 18.

Tandelilin, E. (2001). Analisis Investasi dan Manajemen Portofolio. BPFE. Yogyakarta.

Wijayanto, E., \& Putri, A. N. (2018). Analisis Pengaruh Rasio Likuiditas, Rasio Leverage, Rasio Profitabilitas Dan Kepemilikan Manajerial Terhadap Kebijakan Dividen. Jurnal Aktual Akuntansi Keuangan Bisnis Terapan (AKUNBISNIS), 1(2). 